\title{
Physicochemical, microbiological, and sensory analysis of fermented coffee from Sierra Nevada of Santa Marta, Colombia.
}

\author{
Rosmery Cruz-O’Byrne ${ }^{1}$ (D), Nelson Piraneque-Gambasica1 ${ }^{(1 D}$, Sonia Aguirre-Forero' (iD)
}

${ }^{1}$ Soil, Environment, and Society Research Group/GISAS/, Faculty of Engineering, University of Magdalena, Santa Marta, Colombia

Contact authors: rosmerycruzko@unimagdalena.edu.co,npiraneque@unimagdalena.edu.co, saguirre@unimagdalena.edu.co

Received in August 2, 2020 and approved in October 26, 2020

\begin{abstract}
The evaluation of the physicochemical ( $\mathrm{pH}$, degrees Brix, and temperature), microbiological (fungi, yeasts, and bacteria), and sensory characteristics (sensory attributes, score, and quality classification) of coffee wet fermentation in the Sierra Nevada of Santa Marta (SNSM), Colombia, was carried out to understand its dynamics and the correlation that exists between them. The fermentation process lasted 36 hours and samples were taken every six hours. The $\mathrm{pH}$ and degrees Brix gradually decreased in the fermentation time and showed a high dependence on each other. In 36 hours, the $\mathrm{pH}$ went from 5.37 to 3.96 and the degrees Brix from 6.53 to $4.30^{\circ} \mathrm{Bx}$. Fungi had the most abundant population throughout the fermentation process compared to bacteria and yeasts. The beverages obtained showed a high quality where the classification of excellent specialty coffees prevailed. The highest beverage quality was characterized by its sweetness, high acidity, floral notes flavored with lemongrass and cardamom, it was obtained at 18 hours of fermentation related to the highest fungi ( 6.92 log CFU. $\left.\mathrm{g}^{-1}\right)$ and yeast population $\left(6.01 \mathrm{log}\right.$ CFU.g $\left.{ }^{-1}\right)$ and the lowest bacteria population ( 3.85 log CFU. $\left.\mathrm{g}^{-1}\right)$. Evaluating the physicochemical, microbiological, and sensory characteristics of fermented coffee in the SNSM is important in generating specific knowledge related to the fermentation process and coffee quality in the region and constitutes a tool for future research.
\end{abstract}

Key words: Agroindustry; Coffea arabica; Coffee quality; Cup quality; Wet fermentation.

\section{INTRODUCTION}

Coffee is the major export commodity of around 60 tropical and subtropical countries (Sakiyama; Ferrao, 2015); where Coffea arabica $\mathrm{L}$. species represents around $70-75 \%$ of the total coffee marketed in the world (Aristizábal; Chacón; Cardona, 2017; Waters; Arendt; Moroni, 2017). Followed by Brazil and Vietnam, Colombia ranks third in the main coffee producing countries and the coffee industry is one of the most important in the national economy (International Coffee Organization, ICO, 2020). The Sierra Nevada de Santa Marta (SNSM) is one of the regions of Colombia where coffee is grown; which represents $1.26 \%$ and $2.35 \%$ of the production and national area harvested, respectively (MinAgricultura, 2018).

Due to the characteristics of the Sierra Nevada and its coffee, in 2017 "Café de la Sierra Nevada" is declared as Protected Designation of Origin by the Superintendency of Industry and Commerce (Superintendencia de Industria y Comercio, SIC, 2017). This region has great biodiversity and an ecosystem with the ideal environmental offer for the production of specialty coffees; its farming is characterized by shade-grown coffee systems with a concentration of the harvest between October and February due to the climatic conditions, and as a consequence of the precipitations that appear between the flowering and ripening of the fruits, large beans with greater weight are generated (Federación Nacional de Cafeteros, FNC, 2011). C. arabica $\mathrm{L}$. is cultivated in this region and its processing is mainly by the wet method.
In the wet method, once the coffee cherries are harvested, they are sorted by dumping into water to clean debris and remove floaters fruits, and mechanically depulped to remove the exocarp and mesocarp (Huch; Franz, 2015; Lee et al., 2015). After this, the mucilage is removed by submerged fermentation for 12-48 hours, followed by washing and drying (Evangelista et al., 2014a; Lee et al., 2015; Sakwari et al., 2013).

Within coffee processing, regardless of the method used, the fermentation process has a great influence on the composition of the beans and their beverage quality. The coffee fermentation is a biochemical process carried out by microorganisms such as bacteria, yeasts, and filamentous fungi (Silva et al., 2008), where complex molecules of the mucilage are broken down into simpler molecules producing liquid products and volatile compounds (Haile; Kang, 2019a; Pereira; Soccol; Soccol, 2016).

Despite the potential of the Sierra Nevada de Santa Marta for the production of specialty coffees and the wellknown importance of the fermentation process for the production of them, there are no studies that involve the coffee fermentation process performed in this area. The main goal of this research was to carry out the first investigation in the SNSM related to the fermentation of coffee through the evaluation of physicochemical, microbiological and sensory characteristics and their correlation in the quality of coffee characteristics to generate new knowledge by understanding its dynamics and becoming a tool for Colombian coffee growers and researchers. 


\section{MATERIAL AND METHODS}

\subsection{Coffee processing and sampling}

Coffee cherries of Coffea arabica L. were manually harvested from the farm called "Barlovento" located 1583 to $1759 \mathrm{~m}$ above sea level in the Tagua, Sierra Nevada of Santa Marta, Colombia. The beans were processed at $1619 \mathrm{~m}$ altitude using the wet method traditionally performed by local coffee growers, in which the fermentation process lasts 36 hours. The fresh coffee cherries were mechanically depulped (Estrella \#6; JM Estrada, Antioquia, Colombia) and then submerged in clean water to ferment in a cement tank $(1.65 \mathrm{~m}$ by $3.50 \mathrm{~m}$ by 0.80 $\mathrm{m})$ by 36 hours. The ambient temperature during fermentation was $14-19{ }^{\circ} \mathrm{C}$ and the ambient humidity $69-87 \%$. Samples of $50 \mathrm{~g}$ of depulped coffee beans were collected every six hours $(0,6,12,18,24,30$, and $36 \mathrm{~h})$, placed in sterile Falcon tubes and stored at $-20^{\circ} \mathrm{C}$ for subsequent microbiological analysis at the Biotechnology Laboratory of the University of Magdalena, Santa Marta, Colombia. Physicochemical characteristics of the fermenting mass were analyzed In situ in triplicate at each sampling point,

Additionally, samples of $1 \mathrm{~kg}$ of fermented coffee at $18,24,30$, and $36 \mathrm{~h}$ were collected, which were then washed and dried in the sun for 5 days The criteria to establish these samplings were based on Sakwari et al. (2013), who set a fermentation duration of 12-36 hours depending on the climatic conditions. The dried samples were packed in jute bags and taken to Almacafé ${ }^{\circledR}$ Laboratory of the National Federation of Coffee Growers of Colombia (FNC) in Santa Marta, Colombia, to finish their processing (hulling, roasting, milling) and carry out sensory analysis of the beverage.

\subsection{Physicochemical characteristics analysis}

The physicochemical analysis of the fermenting mass includes the measurement of $\mathrm{pH}$, temperature $\left({ }^{\circ} \mathrm{C}\right)$, and degrees Brix $\left({ }^{\circ} \mathrm{Bx}\right)$. The $\mathrm{pH}$ and temperature were determined using a Multiparameter $\mathrm{pH}$ Meter (HI2020 edge $\mathbb{R}$; Hanna Instruments, Woonsocket, United States), and the degrees Brix with a Refractometer (Abbe-2WAJ; PCE Instruments, Southampton, United Kingdom).

\subsection{Microbiological characteristics analysis}

Microbiological counts of bacteria, fungi, and yeasts were carried out. The fermented coffee beans samples $(10 \mathrm{~g})$ were added to flasks containing $90 \mathrm{~mL}$ of $0,1 \%$ sterile peptone water ( $10^{-1}$ solution)(HiMedia, Mumbai, India), homogenized by gently shaking for 20 minutes and diluted serially $\left(10^{-2}\right.$, $10^{-3}, 10^{-4}$, and $10^{-5}$ ) (Evangelista et al., 2015; Haile; Kang, 2019b; Nasanit; Satayawut, 2015). Nutrient Agar (Oxoid, Basingstoke, United Kingdom) was used to quantify bacteria, Saboraud Dextrose Agar (SDA) (Oxoid, Basingstoke, United
Kingdom) to enumerate fungi and Yeast Extract Glucose Chloramphenicol Agar (YGCA) (BD Difco ${ }^{\mathrm{TM}}$, Franklin Lakes, United States) to count yeasts (Deak, 2003; Luna, $2012,2020)$. Plates were incubated in duplicate at $35^{\circ} \mathrm{C}$ for 24 hours for bacteria and at $27{ }^{\circ} \mathrm{C}$ for 5 days for fungi and yeasts (Luna, 2012, 2020). Colony-forming units (CFUs) of plates containing between 30-300 colonies were counted, the mean of the duplicates was obtained and multiplied by the corresponding dilution factor (Luna, 2012). Finally, the data were expressed as the mean of the decimal logarithm of the CFU per gram of fermented bean (Nasanit; Satayawut, 2015).

\subsection{Sensory characteristics analysis}

The samples were prepared and evaluated according to the cupping protocol of the Specialty Coffee Association (SCA) by Almacafé ${ }^{\circledR}$ Laboratory (Speciality Coffee Association, SCA, 2003). The beverages of each sample were evaluated by a panel of trained coffee tasters belonging to the FNC with Q-Grader Coffee Certificate (Evangelista et al., 2014b). The sensory attributes recorded were fragrance/aroma, flavor, aftertaste, acidity, body, balance, uniformity, clean cup, sweetness, defects, and overall impression (SCA, 2003). After the gustatory step, the tasters provided a description of the sensory characteristics and a final quality score between 0 and 100 for each beverage (Table 1).

Table 1: Total score quality classification of cupping test. Source: SCA (2003).

\begin{tabular}{cc}
\hline Score & Quality Classification \\
\hline$<80.00$ & Below Specialty Quality - Not Specialty \\
$80.00-84.99$ & Very Good - Specialty \\
$85.00-89.99$ & Excellent - Specialty \\
$90.00-100.00$ & Outstanding - Specialty \\
\hline
\end{tabular}

\subsection{Statistical analysis}

The results were recorded in Microsoft Excel ${ }^{\circledR}$. The data of physicochemical, microbiological, and sensory characteristics were evaluated by analysis of variance (ANOVA) and Fisher's LSD test using R Statistical Software to identify significant statistical differences among samples. Besides, a Pearson correlation coefficient analysis was performed to determine the dependency between variables.

\section{RESULTS}

\subsection{Physicochemical and microbiological characteristics}

Physicochemical and microbiological characteristics are shown in Table 2 and Table 3, respectively. There were 
significant statistical differences among samples $(\mathrm{p}<0.05)$ between these characteristics and the fermentation hours.

It is evident from Table 2 that in 36 hours of fermentation, the $\mathrm{pH}$ decreased from 5.37 to 3.96 and the degrees Brix from 6.53 to $4.30^{\circ} \mathrm{Bx}$. The temperature of the fermentation mass had variations over time related to the environmental temperature at the time of taking the samples.

Table 2: Psychochemical characteristics of fermented coffee beans in the Sierra Nevada of Santa Marta, Colombia.

\begin{tabular}{cccc}
\hline \multirow{2}{*}{$\begin{array}{c}\text { Fermentation } \\
\text { time }(\mathrm{h})\end{array}$} & \multicolumn{3}{c}{ Psychochemical characteristics } \\
\cline { 2 - 4 } & $\mathrm{pH}$ & Temperature $\left({ }^{\circ} \mathrm{C}\right)$ & Brix $\left({ }^{\circ} \mathrm{Bx}\right)$ \\
\hline 0 & $5.37 \pm 0.16 \mathrm{D}$ & $22.50 \pm 0.26 \mathrm{D}$ & $6.53 \pm 0.12 \mathrm{C}$ \\
6 & $5.17 \pm 0.12 \mathrm{D}$ & $19.47 \pm 0.12 \mathrm{~B}$ & $6.40 \pm 0.17 \mathrm{C}$ \\
12 & $4.75 \pm 0.14 \mathrm{C}$ & $19.13 \pm 0.60 \mathrm{~B}$ & $5.00 \pm 0.00 \mathrm{~B}$ \\
18 & $4.31 \pm 0.11 \mathrm{~B}$ & $20.87 \pm 0.25 \mathrm{C}$ & $4.93 \pm 0.06 \mathrm{~B}$ \\
24 & $4.10 \pm 0.11 \mathrm{AB}$ & $22.57 \pm 0.31 \mathrm{D}$ & $4.27 \pm 0.65 \mathrm{~A}$ \\
30 & $4.07 \pm 0.12 \mathrm{~A}$ & $19.27 \pm 0.40 \mathrm{~B}$ & $4.30 \pm 0.00 \mathrm{~A}$ \\
36 & $3.96 \pm 0.09 \mathrm{~A}$ & $17.30 \pm 0.26 \mathrm{~A}$ & $4.30 \pm 0.00 \mathrm{~A}$ \\
\hline
\end{tabular}

The letters indicate statistical differences among samples of each characteristic (columns). Mean values with a common letter are not significantly different at $p>0.05$ by Fisher's LSD test.

Table 3: Microbial characteristics of fermented coffee beans in the Sierra Nevada of Santa Marta, Colombia.

\begin{tabular}{cccc}
\hline \multirow{2}{*}{$\begin{array}{c}\text { Fermentation } \\
\text { time }(\mathrm{h})\end{array}$} & \multicolumn{3}{c}{ Microbial population $\left(\log \mathrm{CFU} . \mathrm{g}^{-1}\right)$} \\
\cline { 2 - 4 } & Bacteria & Fungi & Yeasts \\
\hline 0 & $5.14 \pm 0.12 \mathrm{D}$ & $5.11 \pm 0.12 \mathrm{~A}$ & $4.76 \pm 0.01 \mathrm{~B}$ \\
6 & $4.09 \pm 0.01 \mathrm{~B}$ & $6.38 \pm 0.01 \mathrm{~B}$ & $5.91 \pm 0.04 \mathrm{D}$ \\
12 & $4.08 \pm 0.05 \mathrm{~B}$ & $6.19 \pm 0.04 \mathrm{~B}$ & $5.91 \pm 0.00 \mathrm{D}$ \\
18 & $3.85 \pm 0.01 \mathrm{~A}$ & $6.92 \pm 0.08 \mathrm{C}$ & $6.01 \pm 0.15 \mathrm{D}$ \\
24 & $4.98 \pm 0.05 \mathrm{C}$ & $5.18 \pm 0.05 \mathrm{~A}$ & $5.32 \pm 0.04 \mathrm{C}$ \\
30 & $4.84 \pm 0.04 \mathrm{C}$ & $4.95 \pm 0.04 \mathrm{~A}$ & $4.51 \pm 0.01 \mathrm{~A}$ \\
36 & $4.04 \pm 0.10 \mathrm{~B}$ & $5.25 \pm 0.36 \mathrm{~A}$ & $4.72 \pm 0.05 \mathrm{~B}$
\end{tabular}

The letters indicate statistical differences among samples. Mean values with a common letter are not significantly different at $p>0.05$ by Fisher's LSD test.

The microbial population presented variations through the fermentation time. The fungal population was generally the highest during the fermentation process compared to the bacterial and yeast population.

Fungi and yeasts had their maximum population at 18 hours of fermentation; the fungi increased their population from 5.11 to $6.92 \log$ CFU.g $\mathrm{g}^{-1}$ and the yeasts from 4.76 to 6.01 $\log$ CFU.g ${ }^{-1}$. Regarding bacteria, its maximum population appeared at the beginning of the process and decreased until 18 hours; going from 5.14 to $3.85 \log$ CFU.g ${ }^{-1}$. At the end of the 36 hours of fermentation, the fungal population was 5.25 $\log$ CFU. $\mathrm{g}^{-1}$ followed by yeasts $\left(4.72 \log\right.$ CFU.g $\left.{ }^{-1}\right)$ and bacteria (4.04 log CFU.g-g ${ }^{-1}$ (Table 2).

Correlations between physicochemical and microbiological characteristics were identified (Figure 1). Positive correlations were obtained between the degrees Brix and the fungal population $(r=0.99)$, the degrees Brix and the $\mathrm{pH}(\mathrm{r}=0.90)$, the $\mathrm{pH}$ and the yeast population $(\mathrm{r}=0.88)$, the $\mathrm{pH}$ and the fungal population $(\mathrm{r}=0.87)$, as well as between the degrees Brix and the yeast population $(r=0.84)$. Yeast and fungal populations also showed positive dependence ( $\mathrm{r}$ $=0.89$ ) which makes sense because yeasts belong to fungi. Negative correlations were found between the fungi and the bacteria population $(r=-0.73)$ and between degrees Brix and the bacteria population $(\mathrm{r}=-0.70)$.

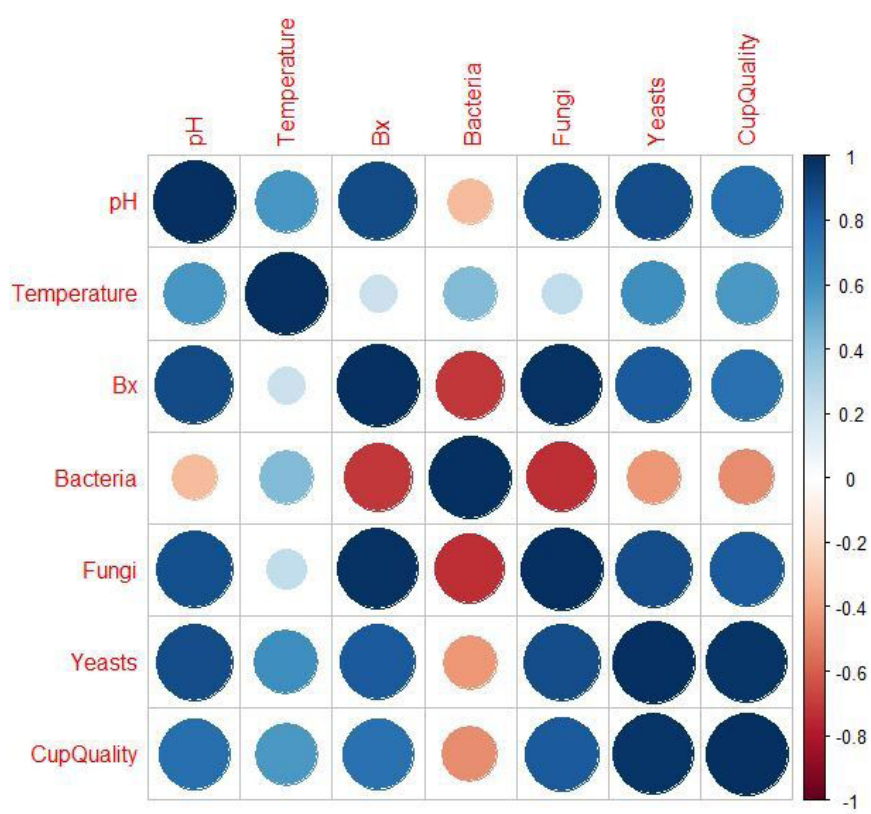

Figure 1: Correlation between the physicochemical, microbiological and sensory characteristics of fermented coffee from the Sierra Nevada of Santa Marta, Colombia.

\subsection{Sensory characteristics}

Regarding the sensory quality of the beverage, the results are reported in Table 4. The highest score was (88.50) obtained with fermented beans for 18 hours, which decreases in the following hours of fermentation. This beverage was characterized by having sweetness, high acidity, and floral flavors such as lemongrass and cardamom, and is classified as excellent specialty coffee (Table 3 ). The highest quality coincided with the highest value of fungal and yeast populations, and the lowest of bacteria.

A high dependency was obtained between the yeast population and the beverage quality $(r=0.98)$ followed by the fungi population and the cup quality $(\mathrm{r}=0.83)$, the $\mathrm{pH}$ and coffee quality $(r=0.76)$, and between the degrees brix and the coffee quality $(r=0.75)$ (Figure 1$)$. 
Table 4: Sensory characteristics of fermented coffee beans in The Sierra Nevada of Santa Marta, Colombia.

\begin{tabular}{cccc}
\hline \multirow{2}{*}{$\begin{array}{c}\text { Fermentation } \\
\text { time }(\mathrm{h})\end{array}$} & \multicolumn{3}{c}{ Cup quality } \\
\cline { 2 - 4 } & Score & Classification & Description \\
\hline 18 & 88.50 & Excellent - Specialty & Sweet, high acidity, floral, lemongrass, cardamom \\
24 & 87.00 & Excellent - Specialty & Sweet, medium-high acidity, lemongrass, cardamom \\
30 & 84.00 & Very good - Specialty & Sweet, balanced, medium acidity, creamy, slightly citric \\
36 & 85.50 & Excellent - Specialty & Sweet, balanced, medium-high acidity, lemongrass \\
\hline
\end{tabular}

\section{DISCUSSION}

The decrease in $\mathrm{pH}$ in the fermentation of Coffea arabica $\mathrm{L}$. by the wet method has been reported in different studies, among which are de Carvalho Neto et al. (2018); Pereira et al. (2016) and Zhang et al. (2019a). The decline in the $\mathrm{pH}$ is due to microbial metabolism during fermentation where organic acids are produced by breaking down coffee mucilage (de Carvalho Neto et al., 2017; Evangelista et al., 2015; Martins et al., 2019).

The decrease in degrees Brix, which refers to the sugar content, can also be explained by the action of microorganisms in the fermentation process since they use sugars as a carbon source for their growth (Elhalis; Cox; Zhao, 2020). The reduction of sugars during fermentation is accompanied by the accumulation of acids such as lactic acid, acetic acid, and succinic acid (de Carvalho Neto et al., 2017; de Carvalho Neto et al., 2018; Elhalis; Cox; Zhao, 2020). This can also be explained when analyzing the Pearson correlation coefficient where a high dependency between the $\mathrm{pH}$ and degrees Brix is evident $(r=0.90)$. Concerning the temperature of the coffee mass during the fermentation process, there were fluctuations according to the atmospheric temperature (Nasanit; Satayawut, 2015; Zhang et al., 2019b).

The finding of the high population of fungi compared to the populations of bacteria and yeasts during the fermentation process obtained in this research contrasts the studies that document bacteria as the most abundant microorganisms during the wet fermentation of $C$. arabica L. (Evangelista et al., 2015; Martins et al., 2020; Zhang et al., 2019b). The increase in yeast and fungal populations relative to their initial population, it has also been reported in different articles (Evangelista et al., 2015; Martins et al., 2019; Nasanit; Satayawut, 2015; Pereira et al., 2016). However, the decrease in the bacterial population in the first hours contrasts with the documented findings that affirm that said population increases (de Melo Pereira et al., 2015; Evangelista et al., 2015; Zhang et al., 2019b). Regarding the negative correlation obtained between the bacteria and fungi populations $(r=-0.73)$, it may be due to reasons of competition between microorganisms (Mille; Fischer; Tranvik, 2006).

The coincidence presented between the highest quality of the beverage with the highest populations of fungi and yeasts at 18 hours of fermentation is supported by Velmourougane (2013) who affirms that the increase in the quality of the coffee beverage is attributed to the increase of the fungal population. Martins et al. (2019) and Ribeiro et al. (2017) documented that yeasts are considered important for the development of flavors and aromas on the final beverage. This last statement is verified by obtaining a high correlation between yeast population and beverage quality $(\mathrm{r}=0.98)$.

\section{CONCLUSIONS}

The fermentation process was mainly characterized by the abundance of fungal populations compared to bacteria and yeasts. Also noteworthy are the findings of increased fungal and yeast populations, and decreased bacterial populations in the first 18 hours, since the highest quality of the coffee beverage was reached in that time; where fungi and yeasts showed their maximum population and bacteria their minimum. This study shows the first effort to understand the characteristics of the coffee fermentation process by the wet method in the Sierra Nevada de Santa Marta, Colombia and the findings reported in this document are expected to become a basis for future studies and decision-making by coffee growers for the optimization of their processes and guarantee a high quality of the coffee beverage.

\section{ACKNOWLEDGMENTS}

The authors are grateful to the University of Magdalena (Unimagdalena) for financial and scientific support, the National Federation of Coffee Growers of Colombia (FNC); especially to the Magdalena Committee for logistical and financial support, and the coffee farmers of the Barlovento farm for support in coffee processing and sampling process.

\section{REFERENCES}

ARISTIZÁBAL, V.; CHACÓN, Y.; CARDONA, C. A. The biorefinery concept for the industrial valorization of coffee processing by-products. In: GALANAKIS, C. M. Handbook of coffee processing by-products: Sustainable applications. London: Academic Press, p.6392, 2017. 
DE CARVALHO NETO, D. et al. Yeast diversity and physicochemical characteristics associated with coffee bean fermentation from the Brazilian Cerrado Mineiro Region. Fermentation, 3(1):1-11, 2017.

DE CARVALHO NETO, D. P. et al. High-throughput rRNA gene sequencing reveals high and complex bacterial diversity associated with brazilian coffee beans fermentation. Food Technology and Biotechnology, 56(1):90-95. 2018.

DE MELO PEREIRA, G. V. et al. Conducting starter culture-controlled fermentations of coffee beans during on-farm wet processing: Growth, metabolic analyses and sensorial effects. Food Research International, 75:348356. 2015.

DEAK, T. Detection, enumeration and isolation of yeasts. In: BOEKHOUT, T.; ROBERT, V. Yeasts in food. Cambridge, United Kingdom: Woodhead publishing. p.39-68, 2003.

ELHALIS, H.; COX, J.; ZHAO, J. Ecological diversity, evolution and metabolism of microbial communities in the wet fermentation of Australian coffee beans. International Journal of Food Microbiology, 321:e108544, 2020.

EVANGELISTA, S. R. et al. Inoculation of starter cultures in a semi-dry coffee (Coffea arabica) fermentation process. Food Microbiology, 44:87-95, 2014a.

EVANGELISTA, S. R. et al. Microbiological diversity associated with the spontaneous wet method of coffee fermentation. International Journal of Food Microbiology, 210:102-112, 2015.

EVANGELISTA, S. R. et al. Improvement of coffee beverage quality by using selected yeasts strains during the fermentation in dry process. Food Research International, 61:183-195, 2014b.

FEDERACIÓN NACIONAL DE CAFETEROS - FNC. Comité Departamental de Cafeteros del Magdalena. In: FEDERACIÓN NACIONAL DE CAFETEROS - FNC. Informe de comités departamentales, caficultura climaticamente inteligente. Bogotá, Colombia: FNC. p.64-70, 2011.

HAILE, M.; KANG, W. H. The role of microbes in coffee fermentation and their impact on coffee quality. journal of Food Quality, 2019:1-6, 2019a.

HAILE, M.; KANG, W. H. Isolation, identification, and characterization of pectinolytic yeasts for starter culture in coffee fermentation. Microorganisms, 7(10):401, 2019b.
HUCH, M.; FRANZ, C. M. A. P. Coffee: Fermentation and microbiota. In: HOLZAPFEL, W. Advances in fermented foods and beverages: improving quality, technologies and health benefits. United Kingdom: Woodhead publishing. p.501-513, 2015.

INTERNATIONAL COFFEE ORGANIZATION - ICO. Coffee production by exporting countries. Monthly Export Statistics (Members \& Non-Members). 2020. Available in: $<$ http://www.ico.org $>$. Access in: June, 20, 2020.

LEE, L. W. et al. Coffee fermentation and flavor - An intricate and delicate relationship. Food Chemistry, 185:182-191, 2015.

LUNA, J. Manual de practicas de laboratorio de Microbiología. Santa Marta, Colombia: Editorial Unimagdalena, 2012. 112p.

LUNA, J. Métodos analíticos de microbiología general y aplicada. Santa Marta, Colombia: Editorial Unimagdalena, 2020. 174p.

MARTINS, P. M. M. et al. Coffee growing altitude influences the microbiota, chemical compounds and the quality of fermented coffees. Food Research International, 129:e108872, 2020.

MARTINS, P. M. M. et al. Production of coffee (Coffea arabica) inoculated with yeasts: impact on quality. Journal of the Science of Food and Agriculture, 99(13):5638-5645, 2019.

MILLE, C.; FISCHER, H.; TRANVIK, L. Antagonism between bacteria and fungi: Substrate competition and a possible tradeoff between fungal growth and tolerance towards bacteria. Oikos, 113(2):233-242, 2006.

MINAGRICULTURA. Agronet: Estadísticas de producción y área cosechada de café en Colombia en 2018. 2018. Available in: $<$ https://www.agronet.gov.co $>$. Access in: June, 20, 2020.

NASANIT, R.; SATAYAWUT, K. Microbiological study during coffee fermentation of Coffea arabica var. chiangmai 80 in Thailand. Kasetsart Journal - Natural Science, 49(1):32-41, 2015.

PEREIRA, G. V. et al. Potential of lactic acid bacteria to improve the fermentation and quality of coffee during onfarm processing. International Journal of Food Science \& Technology, 51(7):1689-1695, 2016.

PEREIRA, G. V.; SOCCOL, V. T.; SOCCOL, C. R. Current state of research on cocoa and coffee fermentations. Current Opinion in Food Science, 7:50-57, 2016. 
RIBEIRO, L. S. et al. Controlled fermentation of semi-dry coffee (Coffea arabica) using starter cultures: A sensory perspective. LWT - Food Science and Technology, 82:32-38, 2017.

SAKIYAMA, N. S.; FERRAO, M. A. G. Botany and production of coffee. In: SCHWAN, R. F.; FLEET, G. H. Cocoa and coffee fermentations. Boca Raton: United States: CRC Press. p.341-365, 2015.

SAKWARI, G. et al. Personal exposure to dust and endotoxin in robusta and arabica coffee processing factories in tanzania. The Annals of Occupational Hygiene, 57(2):173-183, 2013

SILVA, C. et al. Succession of bacterial and fungal communities during natural coffee (Coffea arabica) fermentation. Food Microbiology, 25(8):951-957, 2008.

SPECIALITY COFFEE ASSOCIATION - SCA. Cupping protocols. 2003. Available in: $<$ https://sca.coffee $>$. Access in: June, 22, 2020.

SUPERINTENDENCIA DE INDUSTRIA Y COMERCIO - SIC. La superindustria declara la protección de las denominaciones de origen del "Café de la Sierra Nevada" y el "Café del Tolima". 2017. Available in: $<$ https://www.sic.gov.co>. Access in: June, 22, 2020.

VELMOUROUGANE, K. Impact of natural fermentation on physicochemical, microbiological and cup quality characteristics of arabica and robusta coffee. Proceedings of the National Academy of Sciences, India Section B: Biological Sciences, 83(2):233-239, 2013.

WATERS, D. M.; ARENDT, E. K.; MORONI, A. V. Overview on the mechanisms of coffee germination and fermentation and their significance for coffee and coffee beverage quality. Critical Reviews in Food Science and Nutrition, 57(2):259-274, 2017.

ZHANG, S. J. et al. Influence of various processing parameters on the microbial community dynamics, metabolomic profiles, and cup quality during wet coffee processing. Frontiers in Microbiology, 10:e2621, 2019a.

ZHANG, S. J. et al. Following coffee production from cherries to cup: microbiological and metabolomic analysis of wet processing of Coffea arabica. Applied and Environmental Microbiology, 85(6):e02635-18, $2019 \mathrm{~b}$. 